\title{
EFIKASI HERBISIDA 2,4-D TERHADAP GULMA PADA BUDIDAYA TANAMAN PADI SAWAH (Oryza Sativa L.)
}

\author{
Waskita Apriadi, Dad R. J. Sembodo \& Herry Susanto \\ Jurusan Agroteknologi, Fakultas Pertanian Universitas Lampung \\ Jl.Prof. Soemantri Brodjonegoro, No.1, Bandar Lampung 35145 \\ E-mail:apriadi.waskita89@gmail.com
}

\begin{abstract}
ABSTRAK
Pengendalian gulma dengan herbisida dipilih karena memiliki keuntungan yang lebih besar jika dibandingkan cara pengendalian lain. Pengendalian gulma dilaksanakan sebab gulma dapat menurunkan hasil padi hingga $87 \%$. Penelitiandilakukan bertujuanmengetahui: (1) efikasi herbisida 2,4-D terhadap pertumbuhan gulma pada budidaya tanaman padi sawah; (2)terjadinyaperubahan komposisi jenis gulma pada lahan budidaya padi sawah setelah aplikasi herbisida 2,4-D; dan (3) pengaruh herbisida 2,4-D terhadap tanaman padi sawah. Penelitian dilaksanakan di desa Tempuran kecamatan Trimurjo, kabupaten Lampung Tengah dan Laboratorium Ilmu Gulma Universitas Lampung dari bulan Februari sampai Mei 2012. Perlakuan yang diuji yaitu 2,4-D 0,649 kg ha-1 $\left(0,751 \mathrm{ha}^{-1}\right), 2,4-\mathrm{D} 0,865 \mathrm{~kg} \mathrm{ha}^{-1}\left(1,001 \mathrm{ha}^{-1}\right), 2,4-\mathrm{D} 1,081 \mathrm{~kg} \mathrm{ha}^{-1}\left(1,251 \mathrm{ha}^{-1}\right), 2,4-\mathrm{D} 1,297 \mathrm{~kg} \mathrm{ha}^{-}$ ${ }^{1}\left(1,501 \mathrm{ha}^{-1}\right)$, Metil metsulfuron $0,004 \mathrm{~kg} \mathrm{ha}^{-1}\left(20 \mathrm{~g} \mathrm{ha}^{-1}\right)$, penyiangan mekanis, dan kontrol. Rancangan percobaan menggunakan rancangan acak kelompok (RAK) dengan 4 ulangan. Perbedaan nilai tengah perlakuan diuji dengan Uji Beda Nyata Terkecil (BNT) pada $\alpha=0,05$. Hasil penelitian menunjukkan bahwa: (1) herbisida 2,4-D pada semua taraf dosis yang diuji mampu menekan bobot kering gulma total, bobot kering gulma daun lebar dan teki, tetapi tidak mampu menekan bobot kering gulma rumput pada 3 dan 6 MSA; (2) Terjadi perubahan komposisi gulma akibat aplikasi herbisida yang ditunjukkan dengan jenis dan peringkat dominansi gulma yang tumbuh berbeda pada setiap perlakuan yang dibandingkan dengankontrol (tanpa pengendalian) pada 3 dan 6 MSA; dan (3) Herbisida 2,4-D tidak meracuni dan tidak menekan pertumbuhan dan produksi tanaman padi sawah.
\end{abstract}

Kata kunci: 2,4-D, gulma, herbisida, padi sawah.

\section{PENDAHULUAN}

Olahan padi dinamakan beras. Kebutuhan beras akan terus meningkat sejalan dengan pertambahan jumlah penduduk dan peningkatan konsumsi per kapita akibat peningkatan pendapatan.Namun dilain pihak upaya peningkatan produksi beras saat ini terkendalaoleh berbagai hal seperti konversi lahan subur, penyimpangan iklim, gejala kelelahan teknologi dan penurunan kualitas sumber daya lahan (Pramonoet al., 2005). Adanya gangguan gulma merupakan salah satufaktor penyebab rendahnya produksi padi secara kualitas dan kuantitas. Menurut Sembodo (2010) gulma merupakan tumbuhan yang merugikan kepentingan manusia sehingga manusia berusaha mengendalikannya.

Menurut Smith (1983) gangguan gulma dapat menurunkan hasil gabah $10-25 \%$ pada sistem tanam pindah dan lebih dari $50 \%$ pada sistem tanam benih langsung. Gangguan golongan rerumputan penurunan produksi dapat mencapai $86 \%$, bahkan dapat mencapai $100 \%$ jika ditambah dengan gulma teki dan daun lebar. Oleh karena itu gulma pada lahan pertanian perlu dikendalikan. Salah satu cara pengendalian yang banyak dilakukan oleh petani untuk mengendalikan gulma pada tanaman padi sawah adalah pengendalian dengan menggunakan herbisida.Herbisida yang digunakan dalam penelitian ini yaitu 2,4-Dyang diaplikasi secara pascatumbuh dengan sifat sistemik dan selektif untuk mengendalikan gulma daun lebar dan teki.

Penelitian bertujuan untuk mengetahui efikasi herbisida 2,4-D terhadap pertumbuhan gulma pada budidaya tanaman padi sawah, perubahan komposisi jenis gulma pada lahan budidaya padi sawah setelah aplikasi herbisida 2,4-D serta pengaruh herbisida 2,4-D terhadap pertumbuhan dan produksitanaman padi sawah.

\section{METODE PENELITIAN}

Penelitian dilaksanakan di Desa Tempuran Kecamatan Trimurjo, Kabupaten Lampung Tengah dan Laboratorium Ilmu Gulma Universitas Lampung mulai bulan Februari sampai Mei 2012. Bahan yang digunakan dalam penelitan ini adalah herbisida 2,4-Ddimetil amina $865 \mathrm{~g} \mathrm{l}^{-1}$, herbisida metil metsulfuron, air, pupuk nitrogen

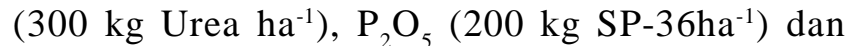
$\mathrm{K}_{2} \mathrm{O}\left(150 \mathrm{~kg} \mathrm{KCL} \mathrm{ha}^{-1}\right)$, dan padi Inpari 13. Alat yang 
digunakan adalah knapsack sprayer bernozzle biru, meteran, oven, dan perlengkapan aplikasi lainnya. Perlakuan yang diuji yaitu 2,4-D $0,649 \mathrm{~kg} \mathrm{ha}^{-1}\left(0,751 \mathrm{ha}^{-}\right.$ $\left.{ }^{1}\right), 2,4-\mathrm{D} 0,865 \mathrm{~kg} \mathrm{ha}^{-1}\left(1,001 \mathrm{ha}^{-1}\right), 2,4-\mathrm{D} 1,081 \mathrm{~kg} \mathrm{ha}^{-1}$ $\left(1,251 \mathrm{ha}^{-1}\right)$, 2,4-D 1,297 kg ha-1 $\left(1,501 \mathrm{ha}^{-1}\right)$,Metil metsulfuron $0,004 \mathrm{~kg} \mathrm{ha}^{-1}\left(20 \mathrm{gha}^{-1}\right)$, penyiangan mekanis, dan kontrol. Rancangan percobaan menggunakan rancangan acak kelompok (RAK) dengan 4 ulangan. Perbedaan nilai tengah perlakuan diuji dengan Uji Beda Nyata Terkecil (BNT) pada $\alpha=0.05$.

Pengolahan tanah dilakukan dengan olah tanah sempurna pada plot berukuran $3 \mathrm{~m}$ x $5 \mathrm{~m}$. Penanaman dilakukan secara sistem tapin (tanam pindah) dengan umur bibit 19 hari setelah sebar,jarak tanam $23 \mathrm{~cm} \times 23$ $\mathrm{cm}$, dan setiap lubang tanam ditanam 2 bibit.Aplikasi herbisida dilakukan 2 minggu setelah tanam (MST) menggunakan alat semprot punggung nozel warna biru. Volume semprot yang didapatkan saat kalibrasi yaitu 4001 ha $^{-1}$.Perlakuan penyiangan mekanis dengan cara mencabut gulma pada 3 dan 6 MST.Pengambilan contoh gulma dilakukan pada dua petak contoh ditentukan secara sistematis berukuran $0,5 \mathrm{~m}$ x 0,5 m. Gulma dari kedua petak contoh dicabut, dibersihkan, dan dipisahkan menurut spesiesnya. Selanjutnya gulma dikeringkan dalam ovenpada temperatur $80^{\circ} \mathrm{C}$ selama 48 jam atau hingga bobot konstan dan ditimbang. Waktu pengambilan gulma dilakukan pada 3 dan 6 MSA.

Peubah yang diamati pada gulma dalam percobaan ini yaitu bobot kering gulma. Selain itu diamati pertumbuhan tanaman meliputi jumlah tanaman per rumpundiamati pada 3, 6 dan 9 MST, tinggi tanaman pada 3,6 dan 7 MST, dan keracunan tanaman pada 1 dan 2 MSA. Komponen hasil seperti jumlah tanaman produktif, bobot gabah 1000 butir, dan hasil gabah per petak panen dengan luas petak panen $2 \mathrm{~m}$ x 1,5 m pada kadar air $14 \%$ diamati saat panen.

\section{HASIL DAN PEMBAHASAN}

Tabel 1 menunjukkan bahwa semua taraf dosis herbisida 2,4-D dan herbisida metil metsulfuron mampu menekan bobot kering gulma totalpada 3 dan 6 MSA. Daya kendali herbisida 2,4-D tersebut sama dengan penyiangan mekanis dan lebih baik daripada metil metsulfuron. Hal ini berarti semua taraf herbisida yg diuji mampu mengendalikan gulma. Herbisida metil metsulfuron merupakan herbisida purna tumbuh yang dapat mengendalikan gulma daun lebar. Menurut Sukman dan Yakub (1995) tumbuhan berdaun lebar (meristem apikal dalam titik tumbuh) lebih banyak menerima herbisida yang disemprot, dibanding dengan tumbuhan yang berdaun sempit dan meristemnya yang terlindungi.Menurut Tomlin (1997) garam amino pada herbisida 2,4-D merupakan formulasi utama yang mudah diabsorpsi oleh akar, sedangkan senyawa ester akan mudah diserap oleh daun. Translokasi terjadi pada selsel yang hidup dengan akumulasi yang utama pada bagian meristem tunas akar sebagai penghambat pertumbuhan sehingga pertumbuhan menjadi tidak normal.

Semua taraf dosis herbisida 2,4-D dan metil metsulfuron mampumengendalikan gulma daun lebar dan teki. Daya kendali antar dosis herbisida 2,4-D tidakberbeda dalam mengendalikan gulma daun lebar dan teki (Tabel 2 dan 3). Selektifitas herbisida merupakan daya kendali herbisida pada salah satu jenis tumbuhan/

Tabel 1. Pengaruh perlakuan herbisida 2,4-D terhadap bobot kering gulma total pada 3 dan 6 MSA

\begin{tabular}{|c|c|c|c|c|}
\hline \multirow{3}{*}{ Perlakuan } & \multicolumn{4}{|c|}{ Bobot kering gulma total $\left(\mathrm{g} / 0,5 \mathrm{~m}^{2}\right)$} \\
\hline & \multicolumn{2}{|c|}{$3 \mathrm{MSA}$} & \multicolumn{2}{|c|}{$6 \mathrm{MSA}$} \\
\hline & Asli & Trans $\vee v(X+0,5)$ & Asli & Trans $\vee \vee(X+0,5)$ \\
\hline $2,4-\mathrm{D} 0,649 \mathrm{~kg} \mathrm{ha}^{-1}$ & 0,28 & $1,17 \mathrm{c}$ & 1,28 & $1,33 \mathrm{c}$ \\
\hline $2,4-\mathrm{D} 0,865 \mathrm{~kg} \mathrm{ha}^{-1}$ & 0,73 & $1,24 \mathrm{c}$ & 2,93 & $1,42 \mathrm{c}$ \\
\hline $2,4-\mathrm{D} 1,081 \mathrm{~kg} \mathrm{ha}^{-1}$ & 2,48 & $1,43 \mathrm{c}$ & 6,95 & $1,63 \mathrm{c}$ \\
\hline $2,4-\mathrm{D} 1,297 \mathrm{~kg} \mathrm{ha}^{-1}$ & 0,03 & $1,11 \mathrm{c}$ & 1,08 & $1,28 \mathrm{c}$ \\
\hline Metil metsulfuron $0,004 \mathrm{~kg} \mathrm{ha}^{-1}$ & 21,50 & $2,13 \mathrm{~b}$ & 36,85 & $2,35 \mathrm{~b}$ \\
\hline Penyiangan mekanis & 0,60 & $1,22 \mathrm{c}$ & 0,38 & $1,18 \mathrm{c}$ \\
\hline Kontrol & 71,75 & $2,87 \mathrm{a}$ & 77,98 & 2,96 a \\
\hline BNT & & 0,38 & & 0,48 \\
\hline
\end{tabular}

Keterangan: Nilai tengah dalam satu kolom yang diikuti huruf yang sama tidak berbeda nyata menurut uji BNT pada $\alpha=0,05$. 
Tabel 2. Pengaruh perlakuan herbisida 2,4-D terhadap gulma daun lebar pada 3 dan 6 MSA

\begin{tabular}{|c|c|c|c|c|}
\hline \multirow{3}{*}{ Perlakuan } & \multicolumn{4}{|c|}{ Gulma daun lebar $\left(\mathrm{g} / 0,5 \mathrm{~m}^{2}\right)$} \\
\hline & \multicolumn{2}{|c|}{3 MSA } & \multicolumn{2}{|c|}{$6 \mathrm{MSA}$} \\
\hline & Asli & Transf $\overline{\sqrt{ }} \sqrt{ }(X+0,5)$ & Asli & Transf $\overline{\sqrt{ }}(X+0,5)$ \\
\hline $2,4-\mathrm{D} 0,649 \mathrm{~kg} \mathrm{ha}^{-1}$ & 0,00 & $1,09 \mathrm{~b}$ & 0,00 & $1,09 \mathrm{~b}$ \\
\hline $2,4-\mathrm{D} 0,865 \mathrm{~kg} \mathrm{ha}^{-1}$ & 0,00 & $1,09 \mathrm{~b}$ & 0,30 & $1,16 \mathrm{~b}$ \\
\hline $2,4-\mathrm{D} 1,081 \mathrm{~kg} \mathrm{ha}^{-1}$ & 0,00 & $1,09 \mathrm{~b}$ & 0,00 & $1,09 \mathrm{~b}$ \\
\hline $2,4-\mathrm{D} 1,297 \mathrm{~kg} \mathrm{ha}^{-1}$ & 0,00 & $1,09 \mathrm{~b}$ & 0,00 & $1,09 \mathrm{~b}$ \\
\hline Metil metsulfuron $0,004 \mathrm{~kg} \mathrm{ha}^{-1}$ & 0,00 & $1,09 \mathrm{~b}$ & 0,45 & $1,18 \mathrm{~b}$ \\
\hline Penyiangan mekanis & 0,13 & $1,13 \mathrm{~b}$ & 0,05 & $1,11 \mathrm{~b}$ \\
\hline Kontrol & 7,65 & $1,75 \mathrm{a}$ & 20,63 & $2,15 \mathrm{a}$ \\
\hline BNT & & 0,19 & & 0,26 \\
\hline
\end{tabular}

Keterangan: Nilai tengah dalam satu kolom yang diikuti huruf yang sama tidak berbeda nyata menurut uji BNT pada $\alpha=0,05$.

Tabel 3. Pengaruh perlakuan herbisida 2,4-D terhadap gulma teki pada 3 dan 6 MSA

\begin{tabular}{|c|c|c|c|c|}
\hline \multirow{3}{*}{ Perlakuan } & \multicolumn{4}{|c|}{ Gulma teki $\left(\mathrm{g} / 0,5 \mathrm{~m}^{2}\right)$} \\
\hline & \multicolumn{2}{|c|}{3 MSA } & \multicolumn{2}{|c|}{$6 \mathrm{MSA}$} \\
\hline & Asli & Trans $\vee \vee(X+0,5)$ & Asli & Trans $\vee \vee(X+0,5)$ \\
\hline $2,4-\mathrm{D} 0,649 \mathrm{~kg} \mathrm{ha}^{-1}$ & 0,18 & $1,15 \mathrm{c}$ & 0,23 & $1,15 \mathrm{~b}$ \\
\hline $2,4-\mathrm{D} 0,865 \mathrm{~kg} \mathrm{ha}^{-1}$ & 0,53 & $1,18 \mathrm{c}$ & 1,95 & $1,35 \mathrm{~b}$ \\
\hline $2,4-\mathrm{D} 1,081 \mathrm{~kg} \mathrm{ha}^{-1}$ & 0,48 & $1,19 \mathrm{c}$ & 0,60 & $1,22 \mathrm{~b}$ \\
\hline $2,4-\mathrm{D} 1,297 \mathrm{~kg} \mathrm{ha}^{-1}$ & 0,00 & $1,09 \mathrm{c}$ & 0,33 & $1,17 \mathrm{~b}$ \\
\hline Metil metsulfuron $0,004 \mathrm{kgha}^{-1}$ & 19,48 & $2,09 \mathrm{~b}$ & 29,13 & $2,23 \mathrm{~b}$ \\
\hline Penyiangan mekanis & 0,35 & $1,18 \mathrm{c}$ & 0,33 & $1,17 \mathrm{~b}$ \\
\hline Kontrol & 59,50 & $2,72 \mathrm{a}$ & 44,18 & $2,58 \mathrm{a}$ \\
\hline BNT & & 0,41 & & 0,45 \\
\hline
\end{tabular}

Keterangan: Nilai tengah dalam satu kolom yang diikuti huruf yang sama tidak berbeda nyata menurut uji BNT pada $\alpha=0,05$.

gulma dan tidak merusak tanaman yang dibudidayakan (Moenandir, 1990). Herbisida 2,4-D lebih baik dalam mengendalikan gulma teki pada 3 MSA dibandingkan dengan perlakuan metil metsulfuron (Tabel 3).

Gulma golongan rumput dan teki merupakan gulma yang sering mengganggu pertumbuhan padi sawah (Adliset al., 2003). Pada 3 MSA, berbagai taraf dosis 2,4-D dapat mengendalikan gulma rumput sama halnya dengan perlakuan mekanis kecuali pada 2,4-D $1,081 \mathrm{~kg} \mathrm{ha}^{-1}$, sedangkan pada herbisida metil metsulfuron tidak mampu mengendalikan gulma rumput. Pada 6 MSA, perlakuan herbisida 2,4-D dan metil metsulfuron tidak dapat mengendalikan gulma rumput (Tabel 4). Hal ini di karenakan herbisida 2,4-D dan metil metsulfuron selektif terhadap gulma daun lebar dan teki.
Pengertian selektifitas herbisida secara umum adalah suatu jenis herbisida yang hanya mematikan satu jenis tumbuhan tanpa mengganggu yang lainnya (Ashton dan Crafts, (1981) dalam Sukman dan Yakub, (1995)).

Data Tabel 5 dan Tabel 6 menunjukkan herbisida 2,4-D pada semua taraf dosis dan herbisida metil metsulfuron mampu mengendalikan gulma daun lebar pada 3 dan 6 MSA pada pertanaman padi sawah. Gulma Fimbristylis miliacea merupakan gulma dominan pada 3 MSA dan 6 MSA.

Jenis gulma dominan ditentukan melalui Summed Dominance Ratio (SDR). Pada hasil pengamatan 3 MSA (Tabel 6) dan 6 MSA (Tabel 7), menunjukkan bahwa aplikasi herbisida dapat mengubah komposisi jenis gulma yang tumbuh. Hal ini dapat dilihat gulma yang 
Tabel 4. Pengaruh perlakuan herbisida 2,4-D terhadap gulma rumput pada 3 dan 6 MSA

\begin{tabular}{|c|c|c|c|c|}
\hline \multirow{3}{*}{ Perlakuan } & \multicolumn{4}{|c|}{ Gulma rumput $\left(\mathrm{g} / 0,5 \mathrm{~m}^{2}\right)$} \\
\hline & \multicolumn{2}{|c|}{3 MSA } & \multicolumn{2}{|c|}{$6 \mathrm{MSA}$} \\
\hline & Asli & Trans $\sqrt{ } \sqrt{ }(\mathrm{X}+0,5)$ & Asli & Trans $\vee \vee(X+0,5)$ \\
\hline 2,4-D $0,649 \mathrm{~kg} \mathrm{ha}^{-1}$ & 0,10 & $1,12 \mathrm{c}$ & 1,05 & $1,28 \mathrm{abc}$ \\
\hline $2,4-\mathrm{D} 0,865 \mathrm{~kg} \mathrm{ha}^{-1}$ & 0,20 & $1,15 \mathrm{bc}$ & 0,68 & $1,20 \mathrm{bc}$ \\
\hline 2,4-D $1,081 \mathrm{~kg} \mathrm{ha}^{-1}$ & 2,00 & $1,39 \mathrm{ab}$ & 6,35 & $1,59 \mathrm{abc}$ \\
\hline 2,4-D 1,297 $\mathrm{kg} \mathrm{ha}^{-1}$ & 0,03 & $1,11 \mathrm{c}$ & 0,75 & $1,24 \mathrm{abc}$ \\
\hline Metil metsulfuron $0,004 \mathrm{kgha}^{-1}$ & 2,03 & $1,39 \mathrm{ab}$ & 7,28 & $1,67 \mathrm{ab}$ \\
\hline Penyiangan mekanis & 0,13 & $1,13 \mathrm{c}$ & 0,00 & $1,09 \mathrm{c}$ \\
\hline Kontrol & 4,60 & $1,52 \mathrm{a}$ & 13,18 & 1,76 a \\
\hline BNT & & 0,26 & & 0,52 \\
\hline
\end{tabular}

Keterangan: Nilai tengah dalam satu kolom yang diikuti huruf yang sama tidak berbeda nyata menurut uji BNT pada $\alpha=0,05$.

Tabel 5. Pengaruh aplikasi herbisida terhadap jenis dan tingkat dominansi gulma pada 3 MSA

\begin{tabular}{lcccccccc}
\hline & \multicolumn{7}{c}{ Summed dominance ratio (\%) } \\
\cline { 2 - 8 } Spesies Gulma & $\mathrm{P} 1$ & $\mathrm{P} 2$ & $\mathrm{P} 3$ & $\mathrm{P} 4$ & $\mathrm{P} 5$ & $\mathrm{P} 6$ & $\mathrm{P} 7$ \\
\hline \multirow{2}{*}{ Daun lebar : Monochoria vaginalis } & 0 & 0 & 0 & 0 & 0 & 0 & 9,24 \\
& Ludwigia hyssopifolia & 0 & 0 & 0 & 0 & 0 & 20 & 11,2 \\
& Sphenolea zeylanica & 0 & 0 & 0 & 0 & 0 & 0 & 5,22 \\
& Lindernia ciliata & 0 & 0 & 0 & 0 & 0 & 0 & 2,38 \\
\multirow{3}{*}{ Teki } & 0 & 0 & 0 & 0 & 0 & 0 & 2,43 \\
& : Cyperus difformis & 17 & 49 & 20 & 0 & 5,6 & 0 & 12 \\
& Cyperus iria & 52 & 14 & 11 & 0 & 68 & 49 & 45,2 \\
\multirow{2}{*}{ Rumput } & Fimbristylis miliacea & 0 & 18 & 11 & 0 & & 0 & 4,99 \\
& : Echinochloa colonum & 0 & 0 & 14 & 100 & 6,4 & 0 & 0 \\
& Echinochloa crusgalli & 31 & 19 & 44 & 0 & 20 & 31 & 7,34 \\
\hline Total & Leptochloa chinensis & 100 & 100 & 100 & 100 & 100 & 100 & 100 \\
\hline
\end{tabular}

Keterangan: P1 = 2,4-D 0,649 kg ha-1, P2 = 2,4-D 0,865 $\mathrm{kg} \mathrm{ha}^{-1}, \mathrm{P} 3=2,4-\mathrm{D} 1,081 \mathrm{~kg} \mathrm{ha}^{-1}, \mathrm{P} 4=2,4-\mathrm{D} 1,297$ $\mathrm{kg} \mathrm{ha}^{-1}, \mathrm{P} 5=$ Metil metsulfuron $0,004 \mathrm{~kg} \mathrm{ha}^{-1}, \mathrm{P} 6=$ Penyiangan mekanis, dan P7 $=$ Kontrol.

tumbuh serta peringkat gulma yang dominan berbeda pada setiap perlakuan yang dibandingkan dengan perlakuan kontrol.

Perubahan komunitas dapat ditentukan bila nilai C $<75 \%$ (Triharso, 1995). Semakin kecil nilai C, semakinbanyak terjadi pergeseran/perubahan komposisi jenis gulma pada perlakuan yang dibandingkan. Tabel 8 memperlihatkan bahwa aplikasi 2,4-D dan metil metsulfuron dapat mengubah komposisi jenis gulma yang tumbuh.

Pada 3 MSA, perubahan komunitas jenis gulma terbesar terjadi pada perlakuan 2,4-D 1,297 $\mathrm{kg} \mathrm{ha}^{-1}$ dengan nilai koefisien (C) $0 \%$. Perubahankomunitas dibuktikan dengan adanya pergeseran perubahan komposisi jumlah spesies gulma dominan yang ada pada petak perlakuan 2,4-D 1,297 $\mathrm{kg} \mathrm{ha}^{-1}$ lebih sedikit dibandingkan dengan perlakuan lain.Pada 6MSA, semua perlakuan terjadi perubahan komunitas $(\mathrm{C}<75 \%)$. perubahan komunitas jenis gulma terbesar terjadi perlakuan penyiangan mekanis dengan nilai $\mathrm{C}$ yaitu $34 \%$. Perubahan komunitas dibuktikan dengan adanya pergeseran perubahan komposisi jumlah spesies gulma dominan yang ada pada perlakuan mekanis lebih sedikit dibandingkan dengan perlakuan lain. Terjadinya perubahan komunitas gulma menunjukkan adanya perubahan pada komunitas gulma dari kondisi tanpa 
Tabel 6. Pengaruh aplikasi herbisida terhadap jenis dan tingkat dominansi gulma pada 6 MSA

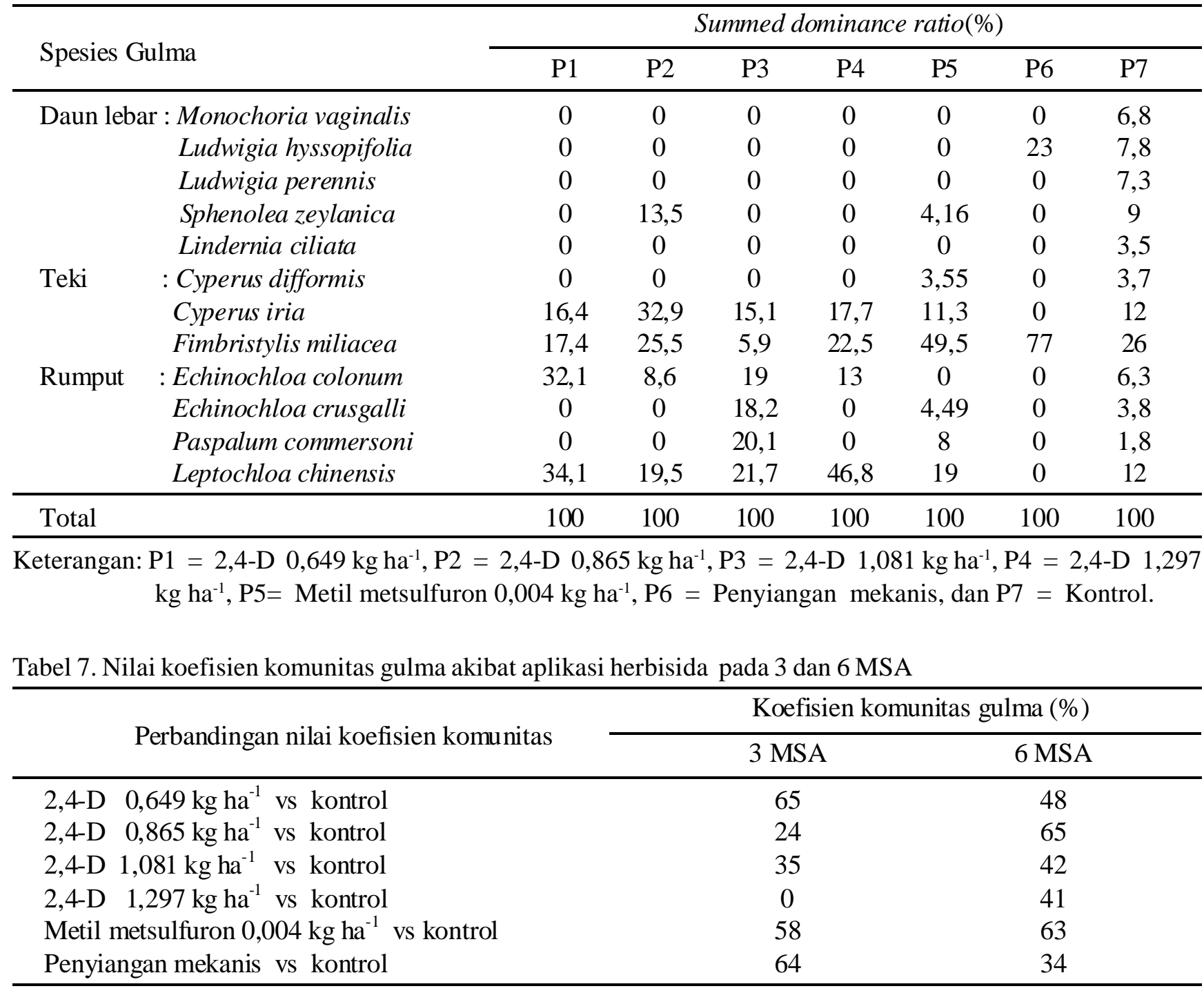

Tabel 8. Pengaruh taraf dosis herbisida terhadap tinggi tanaman padi

\begin{tabular}{|c|c|c|c|}
\hline \multirow{2}{*}{ Perlakuan } & \multicolumn{3}{|c|}{ Tinggi tanaman $(\mathrm{cm})$} \\
\hline & $3 \mathrm{mst}$ & $6 \mathrm{mst}$ & $7 \mathrm{mst}$ \\
\hline $2,4-\mathrm{D} \quad 0,649 \mathrm{~kg} \mathrm{ha}^{-1}$ & $44,02 \mathrm{~b}$ & $80,54 \mathrm{a}$ & $88,92 \mathrm{a}$ \\
\hline $2,4-\mathrm{D} 0,865 \mathrm{~kg} \mathrm{ha}^{-1}$ & $45,24 \mathrm{~b}$ & $80,94 \mathrm{a}$ & $88,76 \mathrm{a}$ \\
\hline $2,4-\mathrm{D} 1,081 \mathrm{~kg} \mathrm{ha}^{-1}$ & $45,41 \mathrm{~b}$ & $81,34 \mathrm{a}$ & $88,79 \mathrm{a}$ \\
\hline $2,4-\mathrm{D} 1,297 \mathrm{~kg} \mathrm{ha}^{-1}$ & $44,42 \mathrm{~b}$ & $81,42 \mathrm{a}$ & $88,97 \mathrm{a}$ \\
\hline Metil metsulfuron $0,004 \mathrm{~kg} \mathrm{ha}^{-1}$ & $46,63 \mathrm{~b}$ & $81,41 \mathrm{a}$ & $89,71 \mathrm{a}$ \\
\hline Penyiangan mekanis & $49,69 \mathrm{a}$ & $83,07 \mathrm{a}$ & $90,65 \mathrm{a}$ \\
\hline Kontrol & $49,77 \mathrm{a}$ & $81,24 \mathrm{a}$ & $86,94 \mathrm{a}$ \\
\hline BNT & 2,96 & 5,15 & 4,93 \\
\hline
\end{tabular}

Keterangan: Nilai tengah dalam satu kolom yang diikuti huruf yang sama tidak berbeda nyata menurut uji BNT pada $\alpha=0,05$. 
pengendalian. Adanya perbedaan tanggapan jenis terhadap herbisida yang diaplikasikan dan kecepatan pertumbuhan gulma dapat menjadi penyebab terjadinya perubahan komunitas gulma. Sehingga memungkinkan tumbuhnya spesies-spesies gulma yang sebelumnya tertekan.

Pengamatan tinggi tanaman padi, pada 3 MST perlakuan herbisida 2,4-D dan metil metsulfuron menekan tinggi tanaman. Hal ini dikarenakan tanaman padi masih berumur muda sehingga tanaman padi masih peka terhadap herbisida. Pada 6 dan 7 MST tinggi tanaman padi antara perlakuan satu dengan lainnya tidak berbeda. Hal ini menunjukkan bahwa penggunaan herbisida tidak menekan pertumbuhan tinggi tanaman terutama 6 dan 7 MST (Tabel 8).

Pada 3 MST semua taraf dosis herbisida yang diuji menekan jumlah tanaman padi per rumpun, kecuali perlakuan metil metsulfuron tidak menekan jumlah tanaman padi per rumpun. Pada 6 MST pengaruh herbisida 2,4-D pada taraf dosis $0,649 \mathrm{~kg} \mathrm{ha}^{-1}$ dan 2,4D $0,865 \mathrm{~kg} \mathrm{ha}^{-1}$ tidak menekan jumlah tanaman padi per rumpun. Seiring penambahan dosis herbisida 2,4-D 1,081 $\mathrm{kg} \mathrm{ha}^{-1}$ dan $1,297 \mathrm{~kg} \mathrm{ha}^{-1}$ menekan jumlah tanaman padi per rumpun. Pada 9 MST,pengaruh perlakuan beberapa taraf dosis herbisida 2,4-D tidak menekan jumlah tanaman padi kecuali pada 2,4-D dosis $1,081 \mathrm{~kg} \mathrm{ha}^{-1}$ dan perlakuan herbisida metil metsulfuron menekan jumlah tanaman per rumpun. Perlakuan kontrol akibat keberadaan gulma dapat menekan jumlah tanaman per rumpun Tabel 9).

Pengamatan keracunan dilakukan secara visual dengan melihat gejala-gejala keracunan pada tanaman padi seperti perubahan warna dan perubahan bentuk daun serta pertumbuhan tanaman tidak normal.

Tabel 8. Pengaruh taraf dosis herbisida terhadap tinggi tanaman padi

\begin{tabular}{|c|c|c|c|}
\hline \multirow{2}{*}{ Perlakuan } & \multicolumn{3}{|c|}{ Tinggi tanaman $(\mathrm{cm})$} \\
\hline & $3 \mathrm{mst}$ & $6 \mathrm{mst}$ & $7 \mathrm{mst}$ \\
\hline 2,4-D $0,649 \mathrm{~kg} \mathrm{ha}^{-1}$ & $44,02 \mathrm{~b}$ & $80,54 \mathrm{a}$ & $88,92 \mathrm{a}$ \\
\hline $2,4-\mathrm{D} 0,865 \mathrm{~kg} \mathrm{ha}^{-1}$ & $45,24 \mathrm{~b}$ & $80,94 \mathrm{a}$ & $88,76 \mathrm{a}$ \\
\hline $2,4-\mathrm{D} 1,081 \mathrm{~kg} \mathrm{ha}^{-1}$ & $45,41 \mathrm{~b}$ & $81,34 \mathrm{a}$ & $88,79 \mathrm{a}$ \\
\hline $2,4-\mathrm{D} 1,297 \mathrm{~kg} \mathrm{ha}^{-1}$ & $44,42 \mathrm{~b}$ & $81,42 \mathrm{a}$ & $88,97 \mathrm{a}$ \\
\hline Metil metsulfuron $0,004 \mathrm{~kg} \mathrm{ha}^{-1}$ & $46,63 \mathrm{~b}$ & $81,41 \mathrm{a}$ & $89,71 \mathrm{a}$ \\
\hline Penyiangan mekanis & $49,69 \mathrm{a}$ & $83,07 \mathrm{a}$ & $90,65 \mathrm{a}$ \\
\hline Kontrol & $49,77 \mathrm{a}$ & $81,24 \mathrm{a}$ & $86,94 \mathrm{a}$ \\
\hline BNT & 2,96 & 5,15 & 4,93 \\
\hline
\end{tabular}

Keterangan: Nilai tengah dalam satu kolom yang diikuti huruf yang sama tidak berbeda nyata menurut uji BNT pada $\alpha=0,05$.

Tabel 9. Pengaruh taraf dosis herbisida terhadap jumlah tanaman padi per rumpun

\begin{tabular}{lccc}
\hline \multirow{2}{*}{ Perlakuan } & \multicolumn{3}{c}{ Jumlah tanaman/rumpun } \\
\cline { 2 - 4 } & $3 \mathrm{mst}$ & $6 \mathrm{mst}$ & $9 \mathrm{mst}$ \\
\hline 2,4-D 0,649 kg ha-1 & $11,65 \mathrm{~cd}$ & $21,98 \mathrm{ab}$ & $20,42 \mathrm{ab}$ \\
2,4-D 0,865 kg ha' & $11,77 \mathrm{~cd}$ & $21,98 \mathrm{ab}$ & $20,02 \mathrm{ab}$ \\
2,4-D 1,081 kg ha & $10,61 \mathrm{~d}$ & $20,33 \mathrm{bc}$ & $18,71 \mathrm{~b}$ \\
2,4-D 1,297 kg ha & $11,38 \mathrm{~cd}$ & $21,21 \mathrm{bc}$ & $19,65 \mathrm{ab}$ \\
Metil metsulfuron 0,004 kg ha-1 & $14,13 \mathrm{ab}$ & $19,27 \mathrm{~cd}$ & $18,48 \mathrm{~b}$ \\
Penyiangan mekanis & $15,23 \mathrm{a}$ & $24,17 \mathrm{a}$ & $20,98 \mathrm{a}$ \\
Kontrol & $13,06 \mathrm{bc}$ & $17,98 \mathrm{~d}$ & $15,42 \mathrm{c}$ \\
\hline \multicolumn{1}{c}{ BNT } & 2,02 & 2,35 & 2,13 \\
\hline
\end{tabular}

Keterangan: Nilai tengah dalam satu kolom yang diikuti huruf yang sama tidak berbeda nyata menurut uji BNT pada $\alpha=0,05$. 
Keracunan tanaman akibat herbisida berdasarkan nilai skoring menunjukkan bahwa aplikasi herbisida 2,4D dan metil metsulfuron pada1 MSA tidak menimbulkan keracunan pada tanaman padi sawah, kecuali pada dosis $1,297 \mathrm{~kg} \mathrm{ha}^{-1}$ dengan tingkat keracunan yang sangat rendah, hal ini berarti bahwa sampai dengan dosis 2,4D $1,081 \mathrm{~kg} \mathrm{ha}^{-1}$ masih aman untuk pertumbuhan padi (Tabel 10). Setelah dilakukan pemupukan nitrogen tanaman mampu melakukan pemulihan pada perlakuan $1,297 \mathrm{~kg} \mathrm{ha}^{-1}$ pada 2 MSA. Bahan aktif herbisida yang dipakai 2,4-D dan metil metsulfuron selektif pada tanaman padi. Menurut (Nyarko dan De Datta, 1991) dalam (Abdulrachman dkk, 1996), padi termasuk tanaman yang toleran terhadap bahan kimia seperti herbisida 2,4-D dan metil metsulfuron, karena padi mampu menghasilkan enzim acetolase yang dapat melindungi pengaruh toksik herbisida.
Penggunaan herbisida 2,4-D pada semua taraf dosis yang diuji tidak menurunkan jumlah tanaman produktif, bobot 1000 butir dan hasil gabah per petak panen (Tabel 11).

Perlakuan metil metsulfuron menurunkan bobot gabah 1000 butir dan menurunkan hasil gabah per petak panen, tetapi tidak berbeda dengan perlakuan herbisida 2,4-D. Keberadaan gulma dapat menurunkan jumlah tanaman produktif, bobot 1000 butir, dan menurunkan hasil gabah per petak panen. Hal ini sesuai menurut Ridwan (1996) dalam Hamim et al.(2003), adanya persaingan gulma dengan tanaman padi mengakibatkan, jumlah tanaman produktif dan hasil akan menurun. Akibat gangguan gulma dapat menurunkan produksi padi sawah secara nasional15 sampai 42\% (Pitoyo, 2006). Perlakuan herbisida 2,4-D memberikan pengaruh yang sama dengan penyiangan mekanis terhadap hasil gabah per

Tabel 10. Pengaruh perlakuan herbisida 2,4-D terhadap keracunan tanaman pada 1 dan 2 MSA

\begin{tabular}{lcc}
\hline \multirow{2}{*}{ Perlakuan } & \multicolumn{2}{c}{ Keracunan tanaman (skoring) } \\
\cline { 2 - 3 } & 1 MSA & 2 MSA \\
\hline 2,4-D $0,649 \mathrm{~kg} \mathrm{ha}^{-1}$ & 0 & 0 \\
2,4-D 0,865 kg ha & 0 & 0 \\
2,4-D 1,081 kg ha' & 0 & 0 \\
2,4-D 1,297 kg ha' & 1 & 0 \\
Mekanis & 0 & 0 \\
Metil metsulfuron 0,004 kg ha & 0 & 0 \\
Kontrol & 0 & 0 \\
\hline
\end{tabular}

Keterangan : $0=$ Tidak ada keracunan: $0-5 \%$ bentuk atau warna daun, atau pertumbuhan tanaman tidak normal. $1=$ Keracunan ringan: $>5-20 \%$ bentuk atau warna daun, atau pertumbuhan tanaman tidak normal.

Tabel 11. Pengaruh taraf dosis herbisida terhadap jumlah tanaman produktif per rumpun,bobot 1000 butir dan hasil gabah per petak panen

\begin{tabular}{|c|c|c|c|c|}
\hline \multirow{2}{*}{ Perlakuan } & \multirow{2}{*}{$\begin{array}{l}\text { Jumlah tanaman } \\
\text { produktif/rumpun }\end{array}$} & \multirow{2}{*}{$\begin{array}{c}\text { Bobot } 1000 \\
\text { butir }(\mathrm{g})\end{array}$} & \multicolumn{2}{|c|}{$\begin{array}{l}\text { Hasil gabah per petak panen } \\
\left(\mathrm{kg} / 3 \mathrm{~m}^{2}\right)\end{array}$} \\
\hline & & & Asli & Trans $\sqrt{ } \sqrt{ }(X+0,5)$ \\
\hline $2,4-\mathrm{D} 0,649 \mathrm{~kg} \mathrm{ha}^{-1}$ & $13,21 \mathrm{a}$ & $26,40 \mathrm{ab}$ & 3,76 & $1,60 \mathrm{ab}$ \\
\hline $2,4-\mathrm{D} 0,865 \mathrm{~kg} \mathrm{ha}^{-1}$ & $13,75 \mathrm{a}$ & $25,71 \mathrm{ab}$ & 3,64 & $1,59 \mathrm{ab}$ \\
\hline $2,4-\mathrm{D} 1,081 \mathrm{~kg} \mathrm{ha}^{-1}$ & $13,04 \mathrm{a}$ & $25,80 \mathrm{ab}$ & 3,69 & $1,59 \mathrm{ab}$ \\
\hline $2,4-\mathrm{D} 1,297 \mathrm{~kg} \mathrm{ha}^{-1}$ & $14,27 \mathrm{a}$ & $27,04 \mathrm{a}$ & 3,55 & $1,59 \mathrm{ab}$ \\
\hline Metil metsulfuron $0,004 \mathrm{~kg} \mathrm{ha}^{-1}$ & $13,25 \mathrm{a}$ & $25,25 \mathrm{~b}$ & 3,23 & $1,56 \mathrm{~b}$ \\
\hline Penyiangan mekanis & $14,58 \mathrm{a}$ & $27,02 \mathrm{a}$ & 4,16 & $1,63 \mathrm{a}$ \\
\hline Kontrol & $9,94 b$ & $25,82 \mathrm{ab}$ & 2,14 & $1,45 \mathrm{c}$ \\
\hline BNT & 1,68 & 1,55 & & 0,05 \\
\hline
\end{tabular}

Keterangan: Nilai tengah dalam satu kolom yang diikuti huruf yang sama tidak berbeda nyata menurut uji BNT pada $\alpha=0,05$. 
petak panen. Hal ini memperlihatkan bahwa herbisida 2,4-D tidak menurunkan produksi gabah per petak panen. Herbisida 2,4-D 0,649 $\mathrm{kg} \mathrm{ha}^{-1}$ sudah mampumemberikan pengaruh yang sama berarti dengan penambahan dosis tidak meningkatkan dayakendali herbisida.Hasil gabah per petak panendidukung oleh jumlah tanaman produktif perrumpun dan bobot gabah 1000 butir, apabila jumlah tanaman produktif per rumpun dan bobot gabah 1000 butir berkurang maka hasil gabah per petak panen menurun. Begitu pula sebaliknya apabila jumlah tanaman produktif per rumpun dan bobot gabah 1000 butir bertambah maka hasil gabah per petak panen meningkat.

\section{KESIMPULAN}

Berdasarkan hasil penelitian yang telah dilakukan, dapat diambil kesimpulan bahwa herbisida 2,4-D pada semua taraf dosis $0,649 \mathrm{~kg} \mathrm{ha}^{-1}\left(0,751 \mathrm{ha}^{-1}\right)-1,297 \mathrm{~kg} \mathrm{ha}^{-}$ ${ }^{1}\left(1,501 \mathrm{ha}^{-1}\right)$ yang diuji mampu menekan bobot kering gulma total, bobot kering gulma daun lebar dan teki, tetapi tidak mampu menekan bobot kering gulma rumput pada 3 dan 6 MSA. Terjadi perubahan komposisi jenis gulma akibat aplikasi herbisida yang ditunjukkan jenis dan peringkat dominansi gulma yang tumbuh berbeda pada setiap perlakuan yang dibandingkan dengan perlakuan kontrol pada 3 dan 6 MSA. Herbisida 2,4-D tidak meracuni pertumbuhandan tidak menekan produksi tanaman padi sawah.

\section{PUSTAKA ACUAN}

Abdulrachman S., E. Sudiatno \& H.M. Toha. 1996. Efektivitas Beberapa Jenis Herbisida untuk Persiapan Lahan dan Pemeliharaan pada Tanaman Padi Sawah. Prosiding II Konferensi
Nasional XIII dan Seminar Ilmiah HIGI. Bandar Lampung.

Adlis, A. \& Z. Lamid. 1998. Perubahan Populasi Gulma Sebelum Tanam Akibat Pemberian Herbisida Glifosat Terus Menerus pada Padi Sawah Sistem Tanpa Olah Tanah. J. Agrotropika III(1): 3843.

Hamim, H., D.R.J. Sembodo \& H. Susanto. 2003. Tanggapan Tanaman Padi Sawah (Oryza sativa, L.) terhadap Pemberian Herbisida Siklosulfamuron dan Quinklorak untuk Mengendalikan Gulma. $J$. Agrotropika VIII(1): 23-30.

Moenandir, J. 1990. Fisiologi Herbisida. Buku Gulma II. Badan Penerbit CV. Rajawali Press. Jakarta.

Pitoyo, J. 2006. Mesin Penyiang Gulma Padi Sawah Bermotor. Sinar Tani.Edisi 5-11 Juli 2006. http:// www.pustaka-deptan.go.id.

Pramono, J., Basuki \& Widarto. 2005. Upaya peningkatan produktivitas padi sawah melalui pendekatan pengelolaan tanaman dan sumber daya terpadu. Agrosains 7(1):1-6.

Sembodo, D.R.J. 2010. Gulma dan Pengelolaanya. Graha Ilmu Yogyakarta.

Smith, R. J. 1983. Weeds of major economic importance in rice and yield losses due to weed competition. $\mathrm{p}$ 19-35. In: Weed Control in Rice. InternationalRice Research Institute. Los Banos.

Sukman, Y. \& Yakup. 1995. Gulma dan Teknik pengendaliannya. CV Rajawali Press. Jakarta.

Tomlin, C.D.S. 1997. The Pesticide Manual. Eleventh Edition. Britsh Crop Protection Council. London.

Triharso. 1995. Dasar-Dasar Perlindungan Tanaman. Gajah Mada University Press. Yogyakarta. 